\section{Pustular Acne}

Q. -What is the best treatment for long-standing, severe pustular acne in a man? It appears to be aggravated by fatty foods.

A.-Many patients with acne seem to find that their eruption is made worse by eating chocolate or other fatty foods. Chocolate and all pork fats are best avoided, and probably also milk fats, including cheese. should be eliminated from the diet. Margarine and vegetable cooking fats are allowed.

The application of sulphur to the skin is usually beneficial. Resorcin and sulphur paste, B.N.F., may be applied at night, and should be washed off again in the morning. If it proves too strong it may be diluted with equal parts of ung. emulsificans. Ultra-violet light is valuable in some cases but not in all. The dose should be one which produces a mild erythema twice weekly for a period of four to six weeks. Exposure to natural sunlight is often helpful.

A short course of an antibiotic is often extremely valuable when pustules are numerous. Chloramphenicol or tetracycline are suitable for this purpose. Sulphonamides are also sometimes used, but their value is not so certain. Most severe cases need $x$-ray treatment, a total of 400 to 600 being given in divided doses over a period of three or four weeks. In this dosage $x$-ray treatment is usually of considerable benefit and has no harmful sequelae.

The management of a severe case requires a good deal of attention on the part of the physician, the treatment being varied according to the progress made and the various methods outlined above used simultaneously or in turn. In a severe case one can seldom hope to clcar up the eruption completely, but it is nearly always possible with perseverance to produce a substantial improvement.

\section{Relieving Cardiospasm}

Q.-What are the best medical means for relieving the symptoms of cardiospasm? Would the passage of a tube after meals relieve the distension of the oesophagus? Has any drug proved useful?

A.-Cardiospasm is due to failure of relaxation of the lower end of the oesophagus. In some cases sniffing octyl nitrite may facilitate swallowing, but usually some form of dilatation is necessary. There is no point in passing a tube after meals, although a mercury bougie may be passed beforehand, but to-day this is seldum done. In practice, any troublesome case is far better after having either a brusque dilatation or a Heller's operation.

\section{Postponement of Immunizations}

Q. -What is the rationale of postponing immunizations in a patient who has either an active infection or may be incubating an infection after a known exposure? Does the type of infection-i.e., viral or bacterial-make any difference to the rule? For how long after recovery should immunizations be postponed?

A.- The main reason for postponing immunizations in these circumstances is that the symptoms resulting from either event-the infection or the immunization-may be exacerbated. This applies to active immunization rather than passive: obviously tetanus antitoxin must be given as soon as possible in tetanus-prone cases, even if the subject may be incubating tetanus. The administration of many vaccines, such as T.A.B., may entail considerable constitutional disturbance, which could aggravate certain co-existing infections. In general, there would be little difference between an overt infection and one which might be late in the incubation period: nor would it matter whether the infection were bacterial or viral.

In addition to true infections, the allergic condition of infantile eczema would preclude vaccination against smallpox.
A history of convulsions would be a contraindication to pertussis vaccination.

One vaccine, T.A.B., has given rise to much discussion from the standpoint of its use in periods of epidemic prevalence of enteric fever. Some authorities believe that in an epidemic vaccination with T.A.B. should be stopped, whereas others think that it should be intensified. There is as yet no agreement on this point.

The period of postponement of various vaccinations need be quite short-generally only as long as it takes for full recovery from the effects of the infection.

\section{Priapism and Chlorothiazide}

Q.-Is painful priapism at night a known complication in male patients receiving chlorothiazide together with a potassium chloride mixture for cardiac insufficiency?

A.-Priapism is not a recognized complication of chlorothiazide treatment. Nor is a potassium mixture likely to have this effect. It seems more probable that the priapism is the result of some local disorder, such as prostatism, or of some generalized disease, and these possibilities should be looked into. Presumably pelvic congestion precipitates the priapism, and it would be interesting to know if a profuse diuresis occurs at night. If so, priapism might be avoided if the diuretic is given only in the morning.

\section{Inheritance of Epilepsy}

Q.-A's grandfather married twice. There were four girls from the second marriage, one of whom has severe epilepsy. $A$ is about to marry one of the other three. What are the chances of their having an epileptic child? None of the 10 children (of whom A's father is one) of the grandfather's first marriage are epileptics.

A.-There is no great risk of this couple having epileptic children. Genetically, they are equivalent to first cousins, but there is no evidence at the moment that grand mal might be due to recessive genes.

\section{NOTES AND COMMENTS}

Ocular Effects of Ultra-violet Light.-Dr. J. P. CariILE (Norwich) writes: With reference to your answer on the ocular effects of ultra-violet light ("Any Questions?" April 30, p. 1378), "Chance's Crookes A glass" should be asked for if one is to be certain of getting the desired optical formula. Which, the journal of the Consumers Association, dealt with this matter in its autumn issue, 1957. It would appear that the patent has expired, so that glasses marked "Crookes lens" or "Crookes glass " need not, and in fact often does not, mean the lens is made from the formula originally patented by Messrs. Chance.

Correction.- In the letter from Mr. Frank Robinson (May 7 , p. 1430) the first sentence of the third paragraph should have ended as follows, "but more (not none) of these cases should be treated by early excision and grafting."

\section{Collected Articles from the "British Medical Journal "}

The following books are available through booksellers or from the Publishing Manager, B.M.A. House. Prices, which include postage, are now the same for both inland and overseas.

Refresher Course for General Practitioners, Volume 3 (26s. 9d.). Clinical Pathology in General Practice (22s. 3d.).

Any Questions?, Volume 3 (8s. 3d.).

All communications with regard to editorial business should be addressed to THE EDI7 OR, British MEDICAL JOURNAL, B.M.A. House, TAVISTOCE SQUARE, LONDON, WC.1. TELEPHONE: EUSTON 4499. TELEGRAMS : Aitiology, Westcent, London. ORIGINAL ARTCLES AND LETJES Medical Journal alone uniess the contrary be stated. Medical Journal alone uniess the contrary be stated. with the Publishing Mana Manager B.M.A. House, Tavistock A B.M.A. House. Tavions MEMLPHONE: EUSTON ${ }^{\prime}$ SUBSCRIPTIONS should be sent to the SECRETARY of the Association. TELEPHONE: EUSTON 4499. TELEORAMS: Medisecta, Westcent, London.

B.M.A. Scotrish OFFICE: 7, Drumsheugh Gardens, Edinburgh. 